\title{
PERBAIKAN GEJALA NEUROPATI PADA PEMBERIAN KOMBINASI VITAMIN B UNTUK PASIEN NEUROPATI DIABETIKUM
}

\section{THE IMPROVEMENT OF NEUROPATHIC SYMPTOMS AFTER VITAMIN B COMBINATION ADMINISTRATION IN DIABETIC NEUROPATHY PATIENTS}

\author{
Rizaldy Taslim Pinzon, Rosa De Lima Renita Sanyasi \\ Fakultas Kedokteran Universitas Kristen Duta Wacana \\ Jl. Dr. Wahidin Sudirohusodo No. 5-25, Kotabaru, Gondokusuman, Yogyakarta, \\ Indonesia, 55224 \\ Email: drpinzon17@gmail.com (Rizaldy Taslim Pinzon)
}

\begin{abstract}
ABSTRAK
Neuropati diabetikum (ND) adalah komplikasi utama yang sering muncul pada pasien diabetes mellitus (DM). Penelitian ini bertujuan untuk menilai efektivitas vitamin B kombinasi terhadap gejala klinis ND dan QoL (kualitas hidup/quality of life) pada pasien DM. Metode yang digunakan dalam penelitian ini adalah metode penelitian one group pre and post test design pada pasien DM dengan ND. Setiap subjek mendapatkan kombinasi vitamin $B$ yang terdiri dari: vitamin $B_{1}$, vitamin $B_{6}$, dan vitamin $B_{12}$ dengan dosis masing-masing secara berurutan: $100 \mathrm{mg}, 100 \mathrm{mg}, 5000 \mathrm{mcg}$. Gejala klinis ND diukur dengan menggunakan Total Symptom Score (TSS). Angka QoL diukur dengan menggunakan kuesioner SF-8. Penilaian gejala dilakukan sebanyak 5 kali, dari penilaian awal hingga 3 bulan. Ada 104 subjek pada awal penelitian. Tujuh subjek tidak dapat mengikuti penelitian sampai selesai, sehingga tersisa 97 subjek pada akhir penelitian. Ada perbaikan gejala ND, yang meliputi sensasi nyeri tertusuk, sensasi nyeri terbakar, kesemutan, dan rasa kebas/baal, setelah pemberian kombinasi vitamin B. Perubahan tersebut bermakna secara statistik $(p<0,0001)$. Hasil serupa juga tampak pada QoL. Ada perbaikan QoL dari awal penelitian hingga akhir penelitian. Perbedaan tersebut bermakna secara statistik (physical component summary dengan $p<0,0001$ dan mental component summary dengan $\mathrm{p}=0,0001$ ). Kombinasi vitamin $\mathrm{B}$ efektif untuk memperbaiki gejala klinis dan meningkatkan kualitas hidup pada pasien ND.
\end{abstract}

Kata kunci: diabetes mellitus, neuropati diabetikum, SF-8, TSS, vitamin B kombinasi. 


\begin{abstract}
Diabetic neuropathy (DN) is a major complication in diabetes mellitus patients. This study measures the effectiveness of vitamin B combination for reducing DN symptoms and improving QoL (quality of life). This study was a pre and post test design on DM patients with DN. Each subject was given vitamin $B$ combination consists of: vitamin $B_{1}$, vitamin $B_{6}$, dan vitamin $B_{12}$, with dosage $100 \mathrm{mg}, 100 \mathrm{mg}$, and $5000 \mathrm{mcg}$, respectively. DN symptoms were measured by using Total Symptom Score (TSS). QoL was measured by using SF-8 questionnaire. Follow-up was performed 5 times, with the total follow up time was 3 months. There were 104 subjects. Seven subjects do not complete the study. It was remained 97 (93.3\%) subjects. Improvement in four DN symptoms (stabbing pain, burning pain, parasthesia, and numbness) showed in this study, compared from the baseline to fifth follow-up. The improvement was significant $(p<0.0001)$. QoL score improved after 3 months medication using vitamin $B$ combination. The differences between baseline score to fifth follow-up score were significant statistically (physical component summary: $p<0.0001$ and mental component summary: $p=0.0001$ ). The use of vitamin B combination is effective to improve symptoms and $Q o L$ in DN patients.
\end{abstract}

Key words: diabetes mellitus, diabetic neuropathy, SF-8, TSS, vitamin B combination. 


\section{Pendahuluan}

Diabetes Mellitus (DM) termasuk penyakit tidak menular yang umum dijumpai. Berdasar pada Riset Kesehatan Dasar 2013, jumlah penderita DM di Indonesia meningkat dari 1,1\% pada tahun 2007 menjadi 2,4\% pada tahun 2013 (Badan Penelitian dan Pengembangan Kesehatan Kementerian Kesehatan Republik Indonesia, 2013).

Nyeri neuropati Diabetikum (ND) adalah komplikasi jangka panjang yang paling sering terjadi pada pasien DM (Pop-Busui dkk., 2017; Papanas dkk., 2011). Kurang lebih 50\% penderita DM tipe 2 akan mengalami neuropati perifer (Kovac dkk., 2011; Tesfaye dkk., 2013). Ada 2 jenis gejala ND yang dapat dijumpai. Gejala positif ND meliputi sensasi nyeri tertusuk, sensasi nyeri terbakar, alodinia, dan sensasi diremas. Gejala negatif ND meliputi kesemutan dan rasa kebas/baal (Burns dan Mauermann, 2011).

Mekanisme terjadinya ND melibatkan banyak faktor, meliputi kerusakan mikrovaskular, neurodegenerasi, keterlibatan jalur polyol, stress oksidatif, dan proses inflamasi (Yagihashi dkk., 2010; Zychowska dkk., 2013). Faktor utama terjadinya ND adalah hiperglikemia.
Faktor lain yang berkontribusi adalah usia lanjut, jenis kelamin laki-laki, durasi penyakit DM, hipertensi, merokok, konsumsi alkohol, dan kadar $\mathrm{HbA1c}>7 \%$, (Deshpande dkk., 2008; do Nascimento dkk., 2016).

Penderita DM dengan komplikasi ND sering memiliki kualitas hidup/quality of life (QoL) yang buruk (Deli dkk., 2013; Hosseini dan Abdollahi, 2013). Hal tersebut berdampak buruk pada kondisi fisik maupun psikologis pasien (Boyd dkk., 2011). Penanganan DM yang efektif, serta pencegahan dan deteksi dini adanya ND akan menghambat perburukan QoL pada pasien. Ada berbagai terapi untuk menangani ND. Salah satu dari terapi tersebut adalah penggunaan kombinasi vitamin $B$. Penelitian di Indonesia terkait penggunaan vitamin B kombinasi pada pasien ND masih terbatas. Tujuan dari penelitian ini adalah mengukur efektivitas pemberian kombinasi vitamin B terhadap gejala klinis dan QoL pada pasien ND.

\section{Metode Penelitian}

Subjek Penelitian

Penelitian ini merupakan penelitian pra eksperimental dengan pengukuran pre dan post intervensi. 
Subjek pada penelitian ini adalah pasien dengan ND. Kriteria inklusi meliputi: (i) laki-laki maupun perempuan, (ii) berusia antara 18 tahun-65 tahun, dan (iii) terdiagnosis ND. Subjek yang memenuhi kriteria dan setuju untuk terlibat dalam penelitian diminta untuk menandatangani lembar persetujuan penelitian yang telah disediakan. Diagnosis ND ditegakkan dengan menggunakan Michigan Neuropathy Screening Instrument (MNSI) atau Toronto Clinical Neuropathy Score (TCNS). MNSI terdiri dari dua bagian, yaitu (i) kuesioner, yang diisi oleh pasien yang terdiri dari 15 pertanyaan dan (ii) pemeriksaan yang dilakukan oleh tenaga medis, terdiri dari inspeksi (pemeriksaan deformitas, kulit kering, kalus, infeksi, fisura, dan ulkus), reflek tendo Achilles, dan sensasi vibrasi (Al-Geffari, 2012; Muntean dkk., 2016). TCNS diperiksa dengan memeriksa gejala neuropati (nyeri kaki, rasa kebas/baal, kesemutan, kelemahan, ataksia), sensoris (pemeriksaan pinprick, suhu, sentuhan ringan, vibrasi, dan propriosepsi), dan pemeriksaan refleks (refleks Achilles dan refleks patela) (Bril dkk., 2009). Pasien dikatakan mengalami neuropati apabila memiliki skor pada pengisian kuesioner MNSI oleh pasien adalah $\geq 7$ dan skor oleh tenaga medis $\geq 2,5$ atau skor TCNS $\geq 6$.

Kriteria eksklusi meliputi: (i) ada riwayat alergi terhadap vitamin B kompleks, (ii) ada riwayat neuropati perifer yang bersifat genetis atau familial, (iii) mengonsumsi suplemen vitamin B kompleks 1 bulan sebelumnya, (iv) ikut dalam penelitian uji klinis lain 1 bulan sebelumnya, (v) sedang hamil, merencanakan kehamilan, atau menyusui, (vi) memiliki riwayat operasi pada saluran gastrointestinal dalam 6 bulan sebelum penjelasan, atau memiliki rencana melakukan operasi dalam masa penelitian, (vii) mengonsumsi obatobatan lambung seperti antasida, H2 blocker, atau proton pump inhibitor dalam 3 bulan sebelum penjelasan.

Intervensi

Setiap subjek penelitian mendapat kombinasi vitamin B dengan komposisi: vitamin B1, vitamin B6, dan vitamin B12, dengan dosis secara berurutan $100 \mathrm{mg}, 100 \mathrm{mg}$, dan 5000 mcg. Kombinasi Vitamin B dikonsumsi satu kali per hari setelah makan selama 3 bulan. Pengukuran evaluasi dikerjakan sebanyak 5 kali, yaitu peninjauan awal, peninjauan kedua pada hari ke- $14 \pm 3$ hari, peninjauan ketiga pada hari ke$30 \pm 3$ hari, peninjauan keempat pada hari 
ke- $60 \pm 3$ hari, dan peninjauan kelima pada hari ke- $90 \pm 3$ hari.

Pada setiap peninjauan dilakukan evaluasi gejala klinis neuropati, pengukuran kualitas hidup, pemeriksaan fisik rutin, pemeriksaan neurologis, dan pemeriksaan tandatanda vital. Pemeriksaan gejala klinis neuropati dilakukan dengan menggunakan Total Symptom Score (TSS). TSS merupakan instrumen yang digunakan untuk menilai frekuensi dan derajat keparahan dari 4 gejala sensoris pada neuropati. Gejala neuropati tersebut meliputi sensasi nyeri tertusuk, sensasi nyeri terbakar, kesemutan, dan rasa kebas/baal (Ziegler dkk., 2009). Pemeriksaan kualitas hidup dinilai dengan menggunakan kuesioner SF-8. Perbaikan gejala klinis dan kualitas hidup pada peninjauan pertama dan peninjauan terakhir akan dinilai.

Analisis

Analisis univariat dilakukan untuk mengetahui karakteristik dasar subjek penelitian. Analisis lebih lanjut dengan menggunakan one-way ANOVA untuk mengidentifikasi adanya perbedaan antar kelompok. Wilcoxon signed rank test digunakan untuk mengetahui perubahan skor rata-rata TSS, sedangkan perubahan skor rata-rata
QoL dianalisis dengan menggunakan Wilcoxon signed rank test.

Kelaikan Etik

Penelitian ini telah melalui pemeriksaan kelaikan etik dan disetujui oleh Komite Etik Fakultas Kedokteran, Universitas Kristen Duta Wacana dengan nomor 166/C.16/FK/2016.

\section{Hasil dan Pembahasan}

Dalam penelitian ini, total terdapat 104 subjek dengan ND. Subjek didominasi oleh laki-laki (61,5\%) dan memiliki usia $>65$ tahun $(94,2 \%)$. Pada akhir penelitian sebanyak 97 (93,3\%) subjek memiliki data follow up lengkap. Ada tujuh subjek yang loss to follow up. Tabel 1 memperlihatkan skor TSS pada pasien ND di penelitian ini.

Hasil penelitian menunjukkan pasien dengan ND memperoleh perbaikan klinis pada bulan ketiga setelah pemberian kombinasi vitamin B. Perbaikan ditunjukkan dengan penurunan skor TSS. Penurunan skor TSS awal $(4,973 \pm 2,1197)$ ke TSS kelima $(1,693 \pm 1,1445)$ yang signifikan secara statistik $\quad(p<0,0001) . \quad$ Tabel 2 memperlihatkan perubahan skor TSS pada kunjungan awal dan pada kunjungan terakhir pada empat gejala ND. 
Tabel 1. TSS pada pasien neuropati diabetikum

\begin{tabular}{lc}
\hline \multicolumn{1}{c}{ Interpretasi TSS } & Neuropati Diabetikum \\
\hline TSS Awal $(n=104)$ & $4,973 \pm 2,1197$ \\
Minimum & 1,00 \\
Maksimum & 10,31 \\
\hline TSS Kelima $(n=97)$ & $1,693 \pm 1,1445$ \\
Minimum & 0,00 \\
Maksimum & 6,32 \\
\hline Rata-rata Penurunan TSS & $3,307 \pm 1,9327$ \\
Persentase Rata-rata & $66,0 \%$ \\
Penurunan TSS & \\
P & $<0,0001$ \\
\hline
\end{tabular}

Keterangan: TSS= Total Symptom Score.

Tabel 2. TSS pada gejala neuropati diabetikum

\begin{tabular}{lcccc}
\hline \multirow{2}{*}{ Interpretasi TSS } & \multicolumn{4}{c}{ Gejala Neuropati Diabetikum } \\
\cline { 2 - 5 } & $\begin{array}{c}\text { Sensasi Nyeri } \\
\text { Tertusuk }\end{array}$ & $\begin{array}{c}\text { Sensasi Nyeri } \\
\text { Terbakar }\end{array}$ & Kesemutan & $\begin{array}{c}\text { Rasa } \\
\text { Kebas/Baal }\end{array}$ \\
\hline TSS Awal $(n=104)$ & $1,364 \pm 0,9083$ & $0,733 \pm 0,9188$ & $1,408 \pm 0,9217$ & $1,468 \pm 1,0171$ \\
Minimum & 0,00 & 0,00 & 0,00 & 0,00 \\
Maksimum & 3,00 & 3,00 & 3,00 & 3,00 \\
TSS Kelima ( $n=97)$ & $0,440 \pm 0,5697$ & $0,120 \pm 0,3995$ & $0,446 \pm 0,5329$ & $0,687 \pm 0,6686$ \\
Minimum & 0,00 & 0,00 & 0,00 & 0,00 \\
Maksimum & 2,66 & 2,33 & 1,66 & 2,66 \\
Rata-rata & $0,954 \pm 0,8932$ & $0,635 \pm 0,8500$ & $0,981 \pm 0,9295$ & $0,737 \pm 0,8565$ \\
Penurunan TSS & & & & $53,2 \%$ \\
Persentase Rata- & $67,7 \%$ & $83,6 \%$ & $68,3 \%$ & $<0,0001$ \\
rata Penurunan TSS & & & & $<0,0001$ \\
p & $<0,0001$ & $<0,0001$ & & \\
\hline
\end{tabular}

Keterangan: TSS= Total Symptom Score.

Tabel 2 menunjukkan gejala ND yang paling menonjol adalah rasa kebas/baal $(1,468 \pm 1,0171)$. Gejala yang paling jarang dirasakan adalah sensasi nyeri terbakar $(0,733 \pm 0,9188)$. Pebaikan pada berbagai gejala ND tersebut ditunjukkan dengan penurunan TSS dari pemeriksaan awal ke peninjauan kelima.
Penurunan TSS dari keempat gejala tersebut bermakna secara statistik $(p<0,0001)$. Sensasi nyeri terbakar merupakan gejala dengan persentase penurunan terbanyak $(83,6 \%)$.

Penelitian ini menunjukkan bahwa pemberian kombinasi vitamin B1, vitamin B6, dan vitamin B12 dengan 
dosis masing-masing sebesar $100 \mathrm{mg}$, $100 \mathrm{mg}$, dan $5000 \mathrm{mcg}$ selama 3 bulan efektif memperbaiki 4 gejala klinis ND. Hal ini tampak dari penurunan TSS dari pertemuan pertama ke pertemuan kelima. Penurunan TSS dari 4 gejala ND tersebut mencapai lebih dari 50\%. Perbaikan dari empat gejala klinis ND tersebut bermakna secara statistik ( $p$ $<0,0001)$.

Hasil penelitian ini serupa dengan penelitian oleh Rizvi dkk. (2013). Penelitian Rizvi dkk. pada 310 pasien ND menunjukkan kombinasi vitamin B1, vitamin B6, dan B12 menunjukkan penurunan nyeri pada $87,4 \%$ dari subjek penelitian (Rizvi dkk., 2013). Hasil penelitian oleh Farvid (2011) menunjukkan pemberian suplementasi B1, B2, B6, biotin, B12, dan asam folat dengan dosis masing-masing $10 \mathrm{mg}, 10$ $\mathrm{mg}, 10 \mathrm{mg}, 200 \mu \mathrm{g}, 10 \mu \mathrm{g}$, dan $1 \mathrm{mg}$, didapatkan penurunan skor MNSI (3,96 menjadi 1,00, $p=0,01)$. Penelitian pada 100 pasien DM tipe 2 menunjukkan 2000 $\mu \mathrm{g}$ vitamin B12 yang diberiksan secara intramuskular sebanyak 2 kali per minggu selama 3 bulan menunjukkan penurunan nyeri yang signifikan jika dibandingkan dengan pasien ND yang diberikan $10 \mathrm{mg}$ nortriptilin setiap malam (Talaei dkk., 2009).

Tabel 3. Skor quality of life

\begin{tabular}{lcccc}
\hline Komponen QoL & PCS & p & MCS & p \\
\hline Skor QoL Awal & $44,142 \pm 6,5215$ & - & $49,198 \pm 9,1910$ & - \\
Skor QoL Ketiga & $47,184 \pm 6,2122$ & $<0,0001$ & $51,298 \pm 7,0736$ & 0,0158 \\
Skor QoL Keempat & $49,332 \pm 6,0685$ & $<0,0001$ & $52,063 \pm 7,1479$ & 0,0132 \\
Skor QoL Kelima & $50,295 \pm 6,3630$ & $<0,0001$ & $53,009 \pm 6,3553$ & 0,0001
\end{tabular}

Keterangan: PCS=Physical Component Summary; MCS=Mental Component Summary; QoL=Quality of Life

Tabel 3 menunjukkan QoL pada pasien dengan ND. Masalah fisik lebih sering dijumpai daripada masalah psikis. Hal tersebut ditunjukkan oleh nilai PCS yang lebih rendah dari MCS. Skor QoL baik PCS maupun MCS selalu mengalami peningkatan, mulai dari peninjauan awal $(\mathrm{PCS}=\quad 44,142 \pm 6,5215 ; \quad M C S=$ $49,198 \pm 9,1910)$ hingga peninjauan akhir $(P C S=\quad 50,295 \pm 6,3630 ; \quad M C S=$ $53,009 \pm 6,3553)$. Perubahan skor QoL dari peninjauan pertama ke peninjauan 
kelima tersebut bermakna secara statistik (PCS <0,0001, MCS=0,0001).

Penelitian ini juga memperlihatkan adanya perbaikan QoL pada pasien dengan ND setelah pemberian kombinasi vitamin B selama 3 bulan. Ada peningkatan skor PCS dan MCS dari peninjauan pertama ke peninjauan kelima. Peningkatan tersebut bermakna secara statistik (PCS $<0,0001$, MCS $=0,0001)$. Hasil ini serupa dengan penelitian Fonseca dkk. (2013). Uji klinik double-blind pada 106 subjek DM tipe 2 yang memperoleh terapi metilfolat, vitamin B6, dan vitamin B12, dengan dosis masing-masing 3, 35, dan $2 \mathrm{mg}$, dibandingkan dengan 108 subjek DM tipe 2 yang mendapatkan plasebo. Hasil dari penelitian tersebut menunjukkan subjek dengan terapi metilfolat $3 \mathrm{mg}$, vitamin B6 35 mg, dan vitamin B12 2 mg mengalami penurunan nyeri, perbaikan gejala klinis, dan peningkatan QoL yang signifikan (Fonseca dkk., 2013).

Pada penelitian ini, komponen fisik lebih sering menimbulkan permasalahan bagi para pasien jika dibandingkan dengan komponen psikologi. Hal ini ditunjukkan dengan skor QoL yang lebih rendah pada PCS mulai dari kunjungan pertama hingga kunjungan kelima. Hasil ini serupa dengan penelitian terdahulu oleh Happich dkk. (2008) dan van Acker dkk. (2009) yang menyatakan permasalahan fisik lebih sering dijumpai pada pasien dengan ND. Penelitian terdahulu yang menyatakan bahwa permasalahan fisik yang sering mengganggu QoL pasien adalah sensasi nyeri terbakar pada kaki, rasa kebas/baal, kelemahan pada kedua kaki, ketidakseimbangan saat berdiri atau berjalan, dan ketidakmampuan dalam melakukan aktivitas hobi. Permasalahan psikis yang sering mengganggu QoL pasien ND adalah adanya perasaan ketergantungan pada pertolongan orang lain, peran dalam keluarga yang berubah, merasa lebih tua dari usia yang seharusnya, merasa hidup menjadi lebih berat, dan merasa malu (Ahmed, 2017).

Terdapat 8 jenis vitamin B, yaitu vitamin B1, B2, B3, B5, B6, B7, B9, dan B12. Vitamin B1 bekerja sebagai antioksidan dan memiliki efek pada nitric oxide-cGMP pathway yang memberikan efek antialodinia dan antihiperalgesia (Alvarado dan Navarro, 2016). Hal tersebut dicapai melalui penghambatan berbagai jalur, meliputi diacylglycerol protein kinase C pathway, advanced glycation end-product formation pathway, dan hexamine pathway (Geller 
dkk., 2017). Defisiensi thiamin umum dijumpai pada pasien DM tipe 2 (Ramos dkk., 2015). Sekitar 75\% penderita DM tipe 2 memiliki kadar thiamin dalam plasma yang rendah (Vin ouc Luong dan Thi Hoang, 2014).

Vitamin B6 bekerja pada kanal kalsium, menghambat sintesis glutamat, dan mengatur metabolisme karbohidrat (Alvarado dan Navarro, 2016). Selain itu, vitamin B6 juga bekerja dengan menghambat pelepasan/release neurotransmitter presinaptik dari serabut saraf nosiseptif, dan menghambat hipereksitabilitas neuron (Geller dkk., 2017).

Vitamin B12 memiliki efek rekonstruktif dan meningkatkan sintesis epidermal growth factor yang merupakan faktor myelotropik (Alvarado dan Navarro, 2016). Vitamin B12 dapat memicu regenerasi saraf dan/atau remyelinasi dengan adanya akumulasi vitamin B12 eksogen. Metformin merupakan salah satu obat yang sering digunakan oleh pasien DM. Penggunaan metformin jangka panjang dihubungkan dengan malabsorpsi vitamin B12 yang menimbulkan defisiensi vitamin B12 (Fatima dan Noor, 2013; Reinstatler dkk., 2012). Defisiensi vitamin B12 tersebut merupakan salah satu pemicu munculnya neuropati perifer pada pasien DM (Jeetendra dan Tushar, 2016), khususnya pada usia $\geq 65$ tahun (Zagar dan Longyhore, 2014). Oleh karena itu, pasien DM yang memperoleh pengobatan metformin jangka lama (>6 bulan) disarankan untuk juga memperoleh suplementasi vitamin B12 untuk mencegah terjadinya ND (Roy dkk., 2016).

Kombinasi dari ketiga vitamin B tersebut dapat menangani berbagai kondisi salah satunya adalah nyeri (Alvarado dan Navarro, 2016). Manfaat dari kombinasi vitamin $B$ tersebut dapat dibedakan menjadi dua, yaitu menurunkan efek kerusakan pada serabut saraf serta efek antinosiseptif dan antihiperalgesia (Mimenza dan Aguilar, 2014).

\section{Kesimpulan}

Pemberian kombinasi vitamin B1, vitamin B6, dan vitamin B12, dengan dosis masing-masing $100 \mathrm{mg}, 100 \mathrm{mg}$, dan 5000 mcg, sebanyak satu kali per hari selama 3 bulan dapat memperbaiki 4 gejala utama ND yang meliputi sensasi nyeri tertusuk, sensasi nyeri terbakar, kesemutan, dan rasa kebas/baal. Pemberian kombinasi vitamin $B$ ini juga 
dapat meningkatkan QoL pasien ND baik

dari segi fisik maupun psikis.

\section{Daftar Pustaka}

Ahmed, A.S. 2017. Assessment of quality of life of patients with diabetic peripheral neuropathy. IOSR Journal of Nursing and Health Science, 6(5):37-46.

Al-Geffari, M. 2012. Comparison of different screening tests for diagnosis of diabetic peripheral neuropathy in primary health care setting. International Journal of Health Sciences Qassim University, 6(2):127-134.

Alvarado, A.M., Navarro, S.A. 2016. Complex B vitamins: physiology and therapeutic effect on pain. American Journal of Pharmacological Sciences, 4(2):2027.

Badan Penelitian dan Pengembangan Kesehatan Kementerian Kesehatan Republik Indonesia. 2013. Riset Kesehatan Dasar (Riskesdas) 2013. Jakarta: Bakti Husada.

Boyd, A., Casselini, C., Vinik, E., Vinik, A. 2011. Quality of life and objective measures of diabetic neuropathy in a prospective placebocontrolled trial of ruboxistaurin and topiramate. Journal of Diabetes Science and Technology, 5(3):715-722.

Bril, V., Tomioka, S., Buchanan, R.A., Perkins, A. 2009. Reliability and validity of the modified Toronto clinical neuropathy score in diabetic sensorimotor polyneuropathy. Diabetic Medicine: a Journal of the British Diabetic Association, 26:240-246.

Burns, T., Mauermann, M. 2011. The evaluation of poluneuropathies. Neurology, 76:S6-13.

Deli, G., Bosnyak, E., Pusch, G., Komoly, S., Feher, G. 2013. Diabetic neuropathies: diagnosis and management.

Neuroendocrinology, 98:267-280.

Deshpande, A.D., Harris-Hayes, M., Schootman, M. 2008. Epidemiology of diabetes and diabetes-related complications. Physical Therapy, 88:1254-1264.

do Nascimento, O.J.M., Pupe, C.C.B., Cavalcanti, E.B.U. 2016. Diabetic neuropathy. Revista Dor, 17(Suppl 1):S46-51.

Farvid, M.S., Homayouni, F., Amiri, Z., Adelmanesh, F. 2011. Improving neuropathy scores in type 2 diabetic patients using micronutrients supplementation. Diabetes Research and Clinical Practice, 93:86-94.

Fatima, S., Noor, S. 2013. A review on effects of metformin on vitamin B12 status. American Journal of Phytomedicine and Clinical Therapeutics, 1(8):652-660.

Fonseca, V.A., Lavery, L.A., Thethi, T.K., Daoud, Y., DeSouza, C., Ovalle, F., Denham, D.S., Bottiglieri, T., Sheehan, P., Rosenstock, J. 2013. Metanx in type 2 diabetes with peripheralneuropathy: a randomized trial. The American Journal of Medicine, 126:141-149. 
Happich, M., John, J., Stamenitis, S., Clouth, J., Polnau, D. 2008. The quality of life and economic burden of neuropathy in diabetic patients in Germany in 2002results from the diabetic microvascular complications (DIMICO) study. Diabetes Research and Clinical Practice, 81:223-230.

Hosseini, A., Abdollahi, M. 2013. Diabetic neuropathy and oxidative stress: therapeutic perspectives. Oxidative Medicine and Cellular Longevity, 2013:168039.

Jeetendra, S., Tushar, B. 2016. Metformin use and vitamin B12 deficiency in patients with type-2 diabetes mellitus. MVP Journal of Medical Sciences, 3(1):67-70.

Kovac, B., Kovac, B., Marusic-Emedi, S., Svalina, S., Demarin, V. 2011. Clinical and electrophysiological signs of diabetic polyneuropathy effect of glycemia and duration of diabetes mellitus. Acta Clinica Croatica, 50:149-157.

Mimenza, A.J., Aguilar, S.G. 2014. Comparative clinical trial of safety and tolerability of gabapentin plus vitamin B1/B12 versus pregabalin in the treatment of painful peripheral. Journal of Pain \& Relief, S3: 1-6.

Muntean, C., Catalin, B., Tudorica, V., Mota, M. 2016. Efficiency of michigan neuropathy screening instrument and nerve conduction studies for diagnosis of diabetic distal symmetric polyneuropathy. Romanian Journal of Diabetes
Nutrition and Metabolic Diseases, 23(1):55-65.

Papanas, N., Vinik, A.I., Ziegler, D. 2011. Neuropathy in prediabetes: does the clock start ticking early? Nature Reviews Endocrinology, 7: 682-690.

Pop-Busui, R., Boulton, A.J.M., Feldman, E.L., Bril, V., Freeman, R., Malik, R.Z., Sosenko, J.M., Ziegler, D. 2017. Diabetic neuropathy: a position statement by the American Diabetes Association. Diabetes Care, 40:136-154.

Ramos, R.V., Laura, G.L.A., Elina, M.C.B., Donaji, B.A.A. 2015. Vitamins and type 2 diabetes mellitus. Endocrine, Metabolic \& Immune Disorders Drug Targets, 15:54-63.

Reinstatler, L., Qi, Y.P., Williamson, R.S., Garn, J.V., Oakley, G.P. 2012. Association of biochemical B12 deficiency with metformin therapy and vitamin B12 supplements. Diabetes Care, 35:327-333.

Rizvi, A., Ahmad, A., Rizvi, Z. 2013. Efficacy of combination of vitamin B1, B6 and B12 in management of diabetic peripheral neuropathy. Pakistan Journal of Medical and Health Sciences, 7(3):801-804.

Roy, R.P., Ghosh, K., Ghosh, M., Acharyya, A., Bhattacharya, A. Pal, M., Chakraborty, S., Sengupta, N. 2016. Study of vitamin B deficiency and peripheral neuropathy in metformin-treated early type 2 diabetes mellitus. Indian Journal of Endocrinology and Metabolism, 20:631-637. 
Talaei, A., Siavash, M., Majidi, H., Chehrei, A. 2009. Vitamin B12 may be more effective than nortriptyline improving painful neuropathy. International Journal of Food Sciences and Nutrition, 60(S5):71-76.

Tesfaye, S., Boulton, A.J., Dickenson, A. 2013. Mechanisms and management of diabetic painful distal symmetrical polyneuropathy. Diabetes Care, 36:2456-2465.

Van Acker, K., Bouhassira, D., De Bacquer, D., Weiss, S., Matthys, K., Raemen, H., Mathieu, C., Colin, I.M. 2009. Prevalence and impact on quality of life of peripheral neuropathy with or without neuropathic pain in type 1 and type 2 diabetic patients attending hospital outpatients clinics. Diabetes \& Metabolism, 35:206213.

Vin ouc Luong, K., Thi Hoang, L. 2012. The impact of the thiamine treatment in the diabetes mellitus. Journal of Clinical Medicine Research, 4(3): 153-160.
Yagihashi, S., Mizukami, H., Sugimoto, K. 2010. Mechanism of diabetic neuropathy: Where are we now and where to go? Journal of Diabetes Investigation, 2(1):18-32.

Zagar, B.R., Longyhore, D.S. 2014. Evaluating the association between vitamin B12 deficiency and peripheral neuropathy in patients with diabetes. International Journal of Medicine and Pharmacy, 2(2):1-10.

Ziegler, D., Movsesyan, L., Mankovsky, B., Gurieva, I., Abylaiuly, Z., Strokov, I. 2009. Treatment of symptomatic polyneuropathy with actovegin in type 2 diabetic patients. Diabetes care, 32:14791484.

Zychowska, M., Rojewska, E., Przewlocka, B., Mika, J. 2013. Mechanisms and pharmacology of diabetic neuropathy experimental and clinical studies. Pharmacological Reports, 65:1601-1610. 